\title{
Sustainable Cement Production with Improved Energy Efficiency and Emerging $\mathrm{CO}_{2}$ Mitigation
}

\author{
Shuangzhen Wang, Xiaochun Han \\ Gaithersburg, Maryland, USA \\ Email: wangshuangzhen@gmail.com
}

Received October 8, 2011; revised November 25, 2011; accepted December 5, 2011

\begin{abstract}
This paper studies the current strategies of energy efficiency improvement, $\mathrm{CO}_{2}$ capture in cement production and fly ash blended cement and concrete. Application of updated technology in newly industrialized countries (especially China) has improved energy efficiency due to their (its) dominant global cement production shares. Waste heat recovery (WHR) increases its energy efficiency. $\mathrm{CO}_{2}$ capture from cement plants will be more efficient than that from pulverized coal fired power plant. This paper will serve as a guide for the technology improvement, energy policy making and environmental protection in cement production.
\end{abstract}

Keywords: Energy Efficiency; $\mathrm{CO}_{2}$ Capture; Fly Ash Cement

\section{Introduction}

Cement demand has increased from 1043 million to 2840 million tonnes in the recent 20 years in Figure 1 [1]. However, the rapid growth comes mainly from the newly industrialized countries. China's cement production was 1390 million tonnes 20 years ago and has increased 7 times since then. Other newly industrialized countries, such as India, Turkey and Brazil, have also played important roles in world cement production; industrialized countries such as United States and Japan have modest increase but they still have significant shares in global cement production, as seen in Table $\mathbf{1}$.

As we know, cement production is one of the five most energy intensive industries that consume about $25 \%$ of total world energy [3]. In 2008, global cement production consumes about $13 \mathrm{EJ}$ energy [1,4] and 30\% - 40\% of cement production cost is energy consumption [5]. The energy input comes from the huge energy demand at high temperatures, calcination of $\mathrm{CaCO}_{3}$ at $850^{\circ} \mathrm{C}$ and the subsequent clinker formation at $1500^{\circ} \mathrm{C}$ [6].

Cement production contributes to $5 \%$ human made $\mathrm{CO}_{2}$. As a calculation base, $1 \mathrm{~kg}$ cement releases about $0.8 \mathrm{~kg} \mathrm{CO}_{2}: 50 \%$ from the fuel combustion and $50 \%$ from the calcination of $\mathrm{CaCO}_{3}$ [3,7]. In 2008, the $\mathrm{CO}_{2}$ emission from cement production in China alone is 776 million tonnes [8]. Consequently, as the major influence of industrial revolution, the atmospheric $\mathrm{CO}_{2}$ has increased by $100 \mathrm{ppm}$ (from 280 to $380 \mathrm{ppm}$ ) since the beginning of industrial revolutions in middle $18^{\text {th }}$ century, which has led to huge global climate change concerns in Figure
$2[9,10]$.

Therefore, increase in energy efficiency, $\mathrm{CO}_{2}$ capture from cement plants and fly ash recycle plays important roles in sustainable and cleaner cement production, which will be addressed below.

\section{Energy Efficiency}

Energy efficiency can be improved through different ways, 1) technology update and 2) waste heat recovery.

\subsection{Technology Update}

Energy efficiency in cement production varies among

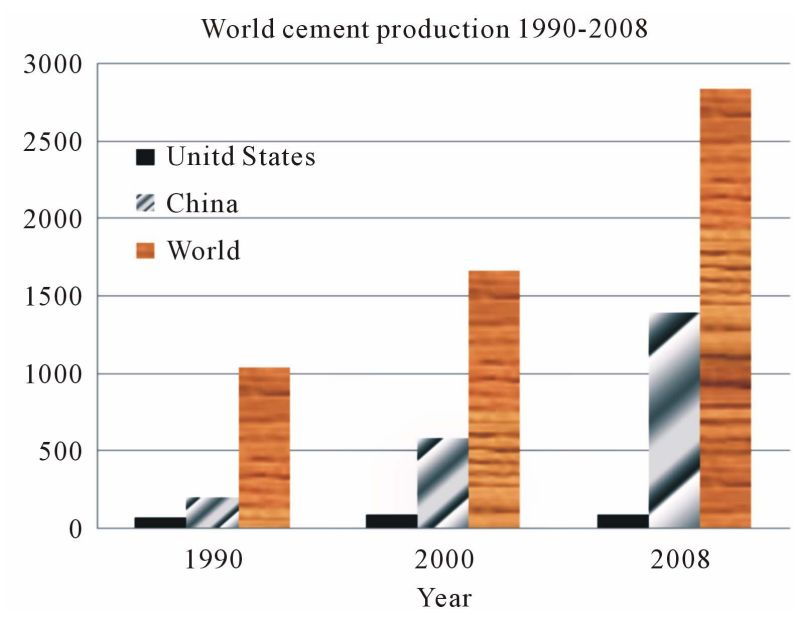

Figure 1. World Cement production from 1990-2008 from [1]. 


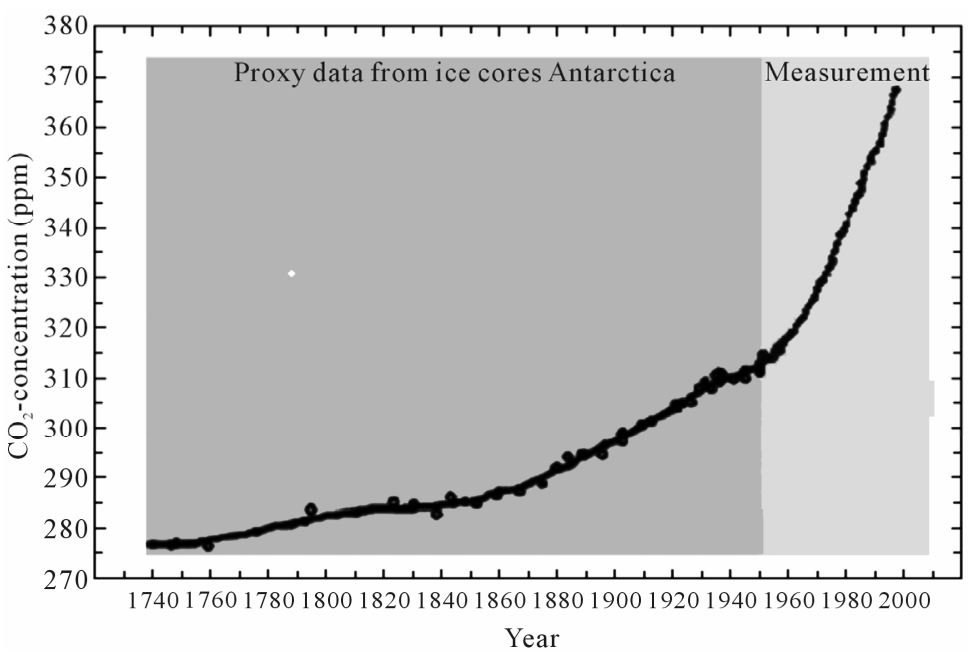

(a)

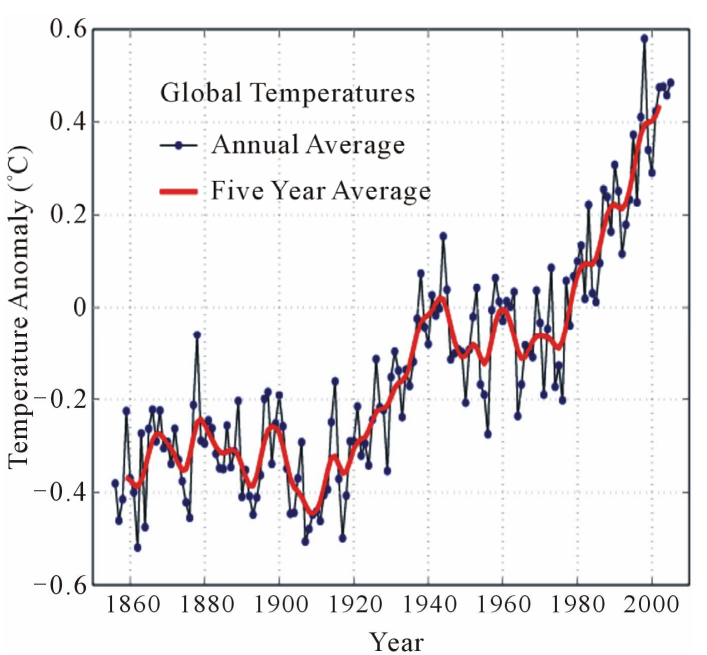

(b)

Figure 2. Global atmospherics $\mathrm{CO}_{2}$ concentration and temperature before and after industrialization.

Table 1. World and major countries cement production (million tonnes) in 2008 from [2].

\begin{tabular}{cc}
\hline Brazil & 51.9 \\
China & 1,390 \\
India & ${ }^{\mathrm{e}} 177$ \\
Japan & 62.8 \\
South Korea & 53.9 \\
Russia & 53.6 \\
Turkey & 51.4 \\
United States & 87.6 \\
Other countries (rounded) & ${ }^{\mathrm{e}} 911.8$ \\
World Total (rounded) & ${ }^{\mathrm{e}} 2,840$ \\
\hline
\end{tabular}

estimated.

different countries in the world. From IEA report [11], it is learned that Japan has the highest energy efficiency in cement production, while China and India are in the middle. Since China dominates the current global cement production with more than $50 \%$ shares, China has put lots of efforts for its technology update.

China's large deployment of New Suspension Preheaters (NSP) illustrated in Figure 3 [12] to replace the shaft kilns has enormously improved energy efficiency and clinker quality. In the recent 14 years, China's NSP share has increased from $1 \%$ to $70 \%$ and enjoys higher energy efficiency and more stable clinker quality [12-14]. The NSP process, by direct contact of the flue gas from cement kilns and with different segmentation (if applicable), has greatly improved the heat exchange between cement kiln and calciner [15]. By comparison, the NSP not only cuts the energy intensity of vertical shaft kiln

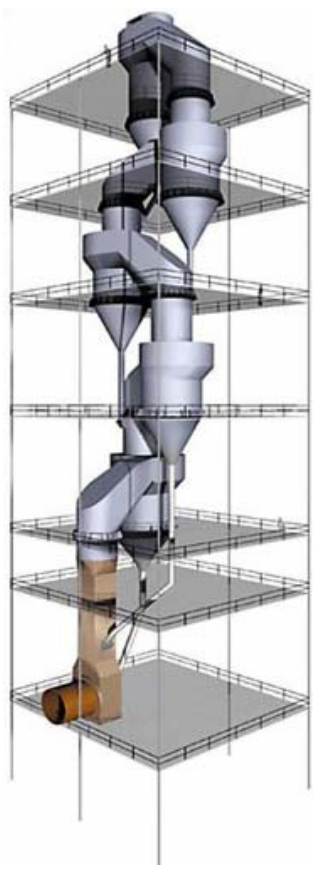

Figure 3. NSP illustration from [15].

from 148 down to $101 \mathrm{~kg}$ coal (equivalent)/tonne clinker, saving up to $1 / 3$ energy input [16], but also increases the calcination of limestone up to $85 \%$ - 95\%, improving the cement quality [14]. However, the segment design increases the pressure drop of the flue gas and needs to be minimized for waste heat recovery as illustrated in Figure 3 [15].

\subsection{Waste Heat Recovery (WHR)}

The clinker formation releases huge amount of heat and the calcination needs significant amount of energy. Therefore, a natural energy exchange between kiln and calci- 
nation has been deployed in cement production, as discussed in the NSP. In addition, there are significant amount of waste heat for recovery, which will increase the energy efficiency and be addressed below.

\subsubsection{Organic Rankine Cycle (ORC)}

Exhaust after clinker cooling and waste gas from preheaters (above $300^{\circ} \mathrm{C}$ ) contains significant amount of energy. For example, the exhaust can easily produce 1.5 $\mathrm{MPa}$ and $320^{\circ} \mathrm{C}$ overheated steam [17]. ORC can take advantage of waste heat from the these sources and apply the organic fluid as an efficient carrying media of thermal energy, going through the compression, evaporation co generation cycle, to generate power for the process. It is designed to match the high laden dust environment and low temperature waste heat, which is ideal for cement production $[18,19]$. Two cases of ORC, with waste heat from 1) clinker cooler air and 2) both clinker cool air and kiln exhaust in USA, have been analyzed for cost and electricity yields: their payback periods range from 6.5 to 9.5 years [20].

\subsubsection{Kaline Cycle (KC)}

Kaline Cycle is also designed for low and medium temperature WHR for power cogeneration. Well known in the refrigeration industry, the working fluid is a mixture of ammonia and water. Ammonia is biodegradable in case of leakage but could be corrosive. It has an efficiency up to $50 \%$ for low temperature heat $\left(200^{\circ} \mathrm{C}-280^{\circ} \mathrm{C}\right)$ and is $20 \%$ - $40 \%$ performance efficient than ORC at medium temperature above $500^{\circ} \mathrm{C}$ [21]. Above all, ammonia is much cheaper than organic liquid.

\section{3. $\mathrm{CO}_{2}$ Capture}

$\mathrm{CO}_{2}$ emission from the exhaust of cement plant is $15 \%$ $33 \%$ by volume and is much higher than that from power plant (3\% - $15 \%$ by volume) $[22,23]$; therefore, $\mathrm{CO}_{2}$ capture from cement production is more efficient and cost effective.

\subsection{Precombustion}

The Integrated Gasification of Combined Cycle (IGCC) may not be an ideal $\mathrm{CO}_{2}$ capture candidate for cement manufacture.

First, the purpose of IGCC is to separate the slag and $\mathrm{SO}_{\mathrm{x}}$ from the coal as syngas and burn it clean. The cement kilns have multiple components of emissions from the raw materials and the slag (ash) finally merges into the raw materials for cement manufacture.

Secondly, the $\mathrm{CO}_{2}$ from power plants has only one source, the fossil fuel; while cement production, has two sources (50\% from fuel combustion and 50\% from calcination of limestone). Therefore, the water shift gas reaction and the separation of dust $/ \mathrm{SO}_{\mathrm{x}}$ will make the process more complicated than that from power plants, if IGCC is applied to cement production.

Thirdly, the cement production has many alternative fuels, such as waste oil, oil shale and used tires, which might not be suitable for gasification at all.

From what is has been discussed above, IGCC can neither meet its primary purpose for slag and emission control nor the objective of $\mathrm{CO}_{2}$ capture. Therefore, precombustion (IGCC) might not serve as an ideal choice for $\mathrm{CO}_{2}$ capture in cement plants.

\subsection{Oxygen Fuel Combustion}

Oxygen fuel combustion can enrich $\mathrm{CO}_{2}$ concentration significantly in cement production, because the $80 \%$ nitrogen from the air has been blocked away. Furthermore, the in loop flue gas at $3500^{\circ} \mathrm{C}$ diluted to fit the requirement of current kiln manufacture materials has enriched $\mathrm{CO}_{2}$ up to $75 \%$ - $80 \%$ by volume.

However, there are several concerns for oxygen fuel combustion in cement production. First, the in loop circulation of flue gas has put more challenges for temperature control at $1500^{\circ} \mathrm{C}$ for clinker formation; furthermore, the in loop circulation has added complexities for the cement production process. The Air Separation Unit (ASU), an important facility for oxygen fuel combustion, is expensive and consumes significant amount of power for routine operation, which makes oxy fuel combustion in cement production economically unattractive [24].

\subsection{Chemical and Physical Separations}

Both organic (amine based) and inorganic solvents (ammonia), which could cause serious corrosion, can be used to scrub $\mathrm{CO}_{2}$ from the hot flue gas $[25,26]$. Amine has been successfully applied to oil refining industry for decades for $\mathrm{CO}_{2}$ capture; however, it is still a challenge for the large scale $\mathrm{CO}_{2}$ capture due to its high cost and corrosion issue. Ammonia is a promising technique, but its critical requirement of precooling of flue gas to $20^{\circ} \mathrm{C}$ causes significant energy consumption.

Membrane is a popular choice for $\mathrm{CO}_{2}$ capture in cement production, which is clean and easy for scale up. However, there are still technical barriers for membrane application: 1) they are not well qualified for the high temperature of flue gas; 2) the high laden dust environment of cement production might block the membranes and lead to malfunction, and 3), the multi components of inpurities will bring more challenge for the membrane such as selectivity and even poisoning $[27,28]$.

Lime has been tested to absorb $\mathrm{CO}_{2}$ with carbonation and calcination as a loop, and it is very convenient and inexpensive for cement production since if can come from the limestone, the bulk raw material of cement production [29]. Furthermore, the technically mature $\mathrm{SO}_{\mathrm{x}}$ 
srubbing with lime spray is a successful precursor for $\mathrm{CO}_{2}$ scrubbing, except that the latter is performed at a higher temperature. However, lime as a $\mathrm{CO}_{2}$ absorbent needs to overcome the quantity and activity loss during the sintering process in the initial 20 cycles [30].

\section{Fly Ash Blended Cement and Concrete}

Coal fly ash can replace cement as high as $50 \%$ by mass, which significantly improves concrete's performances increasing its mechanical strength and making the life span much longer [31,32]. Therefore, the replaced cement will significantly reduce $\mathrm{CO}_{2}$ emission and the according energy input for cement production.

Fly ash has been applied to many big dams in the world, including the world's largest dam, Three Gorge Dam in China in Figure 4 [33,34]. It is 181 meters high and 2,335 meters long. The dam used 26.43 millions of cubic meter concrete, twice that of the Itaipu project in Brazil, the $2^{\text {nd }}$ world largest concrete dam. Fly ash has replaced 30\% cement in the concrete construction of the Three George Dam, improving its mechanical strength, mitigation of Alkali Silica Reactions expansions and reducing its shrinkage [35].

However, there are still many practical and regulatory barriers to fly ash recycle in concrete. In China, the currently accumulated 2 billion tonnes of fly ash that will be doubled in 2020, has occupied 13,000 hectare land and needs more land if it is not disposed properly [36]. In United States, for example in 2008, only $20 \%$ coal fly the ash was recycled in cement and concrete [37].

ASTM C 618 excludes many non coal origin fly ashes from concrete, many of which come from alternative fuels. One example is the newly emerging biomass fly ash. Many comprehensive research results have shown that biomass fly ash can have comparable or better performances (strength and durability) than coal fly ash in cement and concrete [38-43]. Actually, European Union standard EN 450 has allowed up to 20\% straw fired with coal ash in concrete after intensive and long term study. Therefore, inclusion of qualified biomass fly ash and other alternative fuel ashes in ASTM C 618 and other international standards, which will be based on performance in concrete rather than fuel origin and/or processes, saves more land, reduce $\mathrm{CO}_{2}$ emission for cement production and improve concrete's performance.

\section{Discussion and Conclusions}

This paper has discussed the world cement shares, energy efficiency improvement, $\mathrm{CO}_{2}$ capture and fly ash recycle in sustainable cement production. In the following discussions, the cost and investment of the corresponding facility and technology has also been taken into consideration for optimization.

Energy efficiency focuses on the new technology update in China due to its dominant cement share in the world and waste heat recovery that has taken place in the recent decades. The $\mathrm{CO}_{2}$ capture focuses on the technical reliability and cost competitiveness. The blended fly ash cement has seen another route for sustainable cement production because of its multiple benefits: reducing cement production and thus relieving the energy/environmental issues (including $\mathrm{CO}_{2}$ capture), and recycle of industrial byproduct and the concrete performance improve-

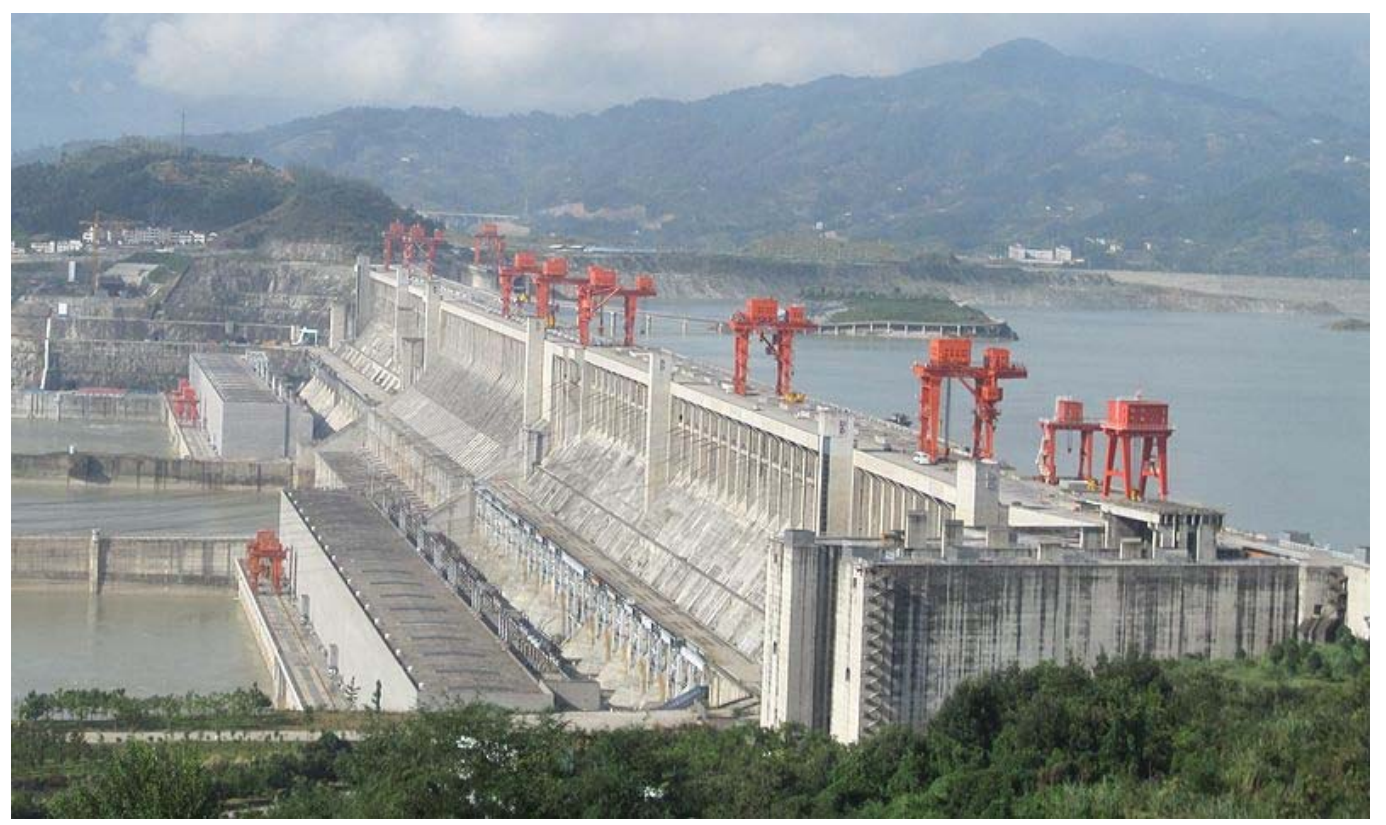

Figure 4. Three Gorge Dam [33]. 
ment. The specific statements and conclusions can be listed as below for cement manufacturers and the related regulatory agencies to make appropriate decisions:

1) New Suspension Preheater (NSP), which introduces direct contact between high temperature kiln exhaust and the clacination zone, makes the high quality heat exchange more efficient and saves almost 1/3 energy for cement manufacture in China, which has the dominant cement production share in the world.

2) Waste Heat Recovery in cement production, such as Organic Rankine or Kalina Cycle, will take advantage of low grade heat (for example, from the preheating exhaust and clinker cooling) in the range of $300^{\circ} \mathrm{C}-500^{\circ} \mathrm{C}$ for cogeneration, and significantly improve energy efficiency in cement production.

3) $\mathrm{CO}_{2}$ capture is more efficient and technology feasible in cement production than fossil fuel fired power plants: lime looping seems to be a good fit because of its technical reliability and inexpensive/convenient raw material limestone in cement production.

4) Fly ash either from coal or from alternative fuels should be studied further for recycle in cement/concrete to reduce the energy input and the $\mathrm{CO}_{2}$ emission for cement production.

\section{REFERENCES}

[1] USGS Cement Statistics, http://minerals.usgs.gov/ds/2005/140/cement.pdf

[2] H. G. van Oss, "US and World CEMENT Production 2008 and 2009,” USGS Online Survey, 2010.

[3] W. T. Choate, "Energy and Emission Reduction Opportunities for the Cement Industry,” Prepared under Contract for: Industrial Technologies Program, US DOE Energy Efficiency and Renewable Energy, 29 December 2003.

[4] M. Taylor, C. Tam and D. Gielen "Energy Efficiency and $\mathrm{CO}_{2}$ Emissions from the Global Cement Industry,” Energy Efficiency and $\mathrm{CO}_{2}$ Emission Reduction Potentials and Policies in the Cement Industry, IEA, Paris, 4-5 September 2006.

[5] N. T. Zheng and G. David, "How Can China Lighten up? Urbanization, Industrialization and Energy Demand Scenarios," US Department of Energy under Contract No. DE-AC02-05CH11231, Lawrence Berkeley National Laboratory, LBNL Paper LBNL-3527E, July 2009.

[6] H. F. W. Taylor, “Cement Chemistry,” Thomas Telford Publishing, Singapore City, 1997. doi:10.1680/cc.25929

[7] C. A. Hendriks, E. Worrell, D. DeJager, K Block and P. Riemer, "Emission Reduction of Greenhouse Gases from the Cement Industry," IEA Greenhouse gas R\&D Programme, 2000. http://www.ieagreen.org.uk/prghgt42.htm

[8] T. Sui Presentation "A Brief on China Cement StatusTowards a Sustainable Industry,” IEA-BEE International Workshop on Industrial Energy Efficiency, New Dehli,
27-28 January 2010.

[9] E. G. Beck, “180 Years Atmospheric $\mathrm{CO}_{2}$ Gas Analysis by Chemical Method," Energy and Environment, Vol. 18, No. 2, 2007. doi:10.1260/095830507780682147

[10] http://www.cheaperpetrolparty.com/Global_Warming.php

[11] International Energy Agency, "The Reduction of Greenhouse Gas Emissions from the Cement Industry,” IEA, Paris, 1999.

[12] http://www.cbminfo.com/eng/tabid/1394/InfoID/291312/ Default.aspx

[13] APP China Cement Task Force, "Status Report of China Cement Industry," 8th CTF Meeting, Vancouver, 24 March 2010.

[14] Z. G. Yuan and H. Liu, "Soft Sensor for Apparent Degree of Calcination in NSP Cement Production Line,” The 2nd International Conference on Computer and Automation Engineering (ICCAE), Singapore City, 26-28 February 2010 pp. 473-478.

[15] http://www.flsmidth.com

[16] A. Hasanbeigi, L. Price, H. Lu and L. Wang, “Analysis of Energy-Efficiency Opportunities for the Cement Industry in Shandong Province, China: A Case Study of $16 \mathrm{Ce}-$ ment Plants,” Energy, Vol. 35, 2010, pp. 3461-3473. doi:10.1016/j.energy.2010.04.046

[17] Q. Yan, C. Zhou, P. Qu and R. Zhang, “The Promotion of Clean Development Mechanism to Cement Industry Capturing Waste Heat for Power Generation in China,” Mitigation Adapt Strategy Global Change, Vol. 14, No. 8, 2009, pp. 793-804. doi:10.1007/s11027-009-9199-0

[18] J. Wang, Y. Dai and L. Gao, "Energy Analyses and Parametric Optimizations for Different Cogeneration Power Plants in Cement Industry,” Applied Energy, Vol. 86, No. 6, 2009, pp. 941-948. doi:10.1016/j.apenergy.2008.09.001

[19] P. S. Bundela and V. Chawla, "Sustainable Development through Waste Heat Recovery,” American Journal of Environmental Sciences, Vol. 6, No. 1, 2010, pp. 83-89. doi:10.3844/ajessp.2010.83.89

[20] K. Umamaheswar, “Waste Heat Recovery,” US Department of Energy Gulf Coast Clean Energy Application Center Cement Industry Online Webinar, 26 May 2011.

[21] M. D. Mirolli “Cementing Kalina Effectiveness,” IEEE Industry Applications Magazine, July-August 2006. www.ieee.org/ias

[22] E. Worrell, L. Price, N. Martin, C. Hendriks and O. L. Meida, "Carbon Dioxide Emissions from the Global Cement Idustry," Annual Review Energy Environment, Vol. 26, 2001, pp. 303-329. doi:10.1146/annurev.energy.26.1.303

[23] J. Marion, N. Nsakala, T. Griffin and A. Bill, "Controlling Power Plant $\mathrm{CO}_{2}$ Emissions: A Long Range View," 1st National Conference on Carbon Sequestration, National Energy and Technology Laboratory, 14-17 May 2001.

[24] D. J. Barker, S. A. Turner, P. A. Napier-Moore, M. Clark M. and J. M. Davison, " $\mathrm{CO}_{2}$ Capture in Cement Industry,” Energy Procedia, Vol. 1, No. 1, 2009, pp. 87-94. 
doi:10.1016/j.egypro.2009.01.014

[25] C. Alie, L. Backham, E. Croiset and P. L. Douglas, "Simulation of $\mathrm{CO}_{2}$ Capture Using MEA Scrubbing: A Flowsheet Decomposition Method," Energy Conversion and Management, Vol. 46, No. 3, 2005, pp 475-487. doi:10.1016/j.enconman.2004.03.003

[26] M. T. Ho, G. W. Allinson and D. E. Wiley, "Comparison of MEA Capture Cost for Low $\mathrm{CO}_{2}$ Emissions Sources in Australia," International Journal of Greenhouse Gas Control, Vol. 5, No. 1, 2010, pp. 49-60. doi:10.1016/j.ijggc.2010.06.004

[27] R. Bounaceur, N. Lape, D. Roizard, C. Vallieres and E. Favre, "Membrane Processes for Post-Combustion Carbon Dioxide Capture: A Parametric Study," Energy, Vol. 31, No. 14, 2006, pp. 2556-2570. doi:10.1016/j.energy.2005.10.038

[28] M. C. Trachtenberg, R. M. Cowan, D. A. Smith, D. A. Horazak, M. D. Jensen, J. D. Laumb, A. P. Vucelic, H. Chen, L. Wang and X. Wu, "Membrane-Based, Enzyme-Facilitated, Efficient Carbon Dioxide Capture,” Energy Procedia, Vol. 1, 2009, pp. 353-360. doi:10.1016/j.egypro.2009.01.048

[29] V. Manovic and E. J. Anthony, "Lime-Based Sorbents for High-Temperature $\mathrm{CO}_{2}$ Capture-A Review of Sorbent Modification Methods," International Journal of Environmental Research and Public Health, Vol. 7, No. 8, 2010, pp. 3129-3140. doi:10.3390/ijerph7083129

[30] C. Abanades, "Calcium Sorbent Cycling for Simultaneous $\mathrm{CO}_{2}$ Capture and Clinker Production,” Presented at GCEP Stanford, 22 April 2008.

[31] R. Helmuth, "Fly Ash in Cement and Concrete,” Portland Cement Association, June 1987.

[32] S. Mindness, F. J. Young and D. Darwin, “Concrete,” 2nd Edition, Prentice Hall, Upper Saddle River, 30 August 2002.

[33] http://www.cnn.com/SPECIALS/1999/china.50/asian.sup erpower/three.gorges/ 2011.

[34] P. W. Gao, S. X. Wu, P. H. Lin, Z. R. Wu and M. S. Tang,
"Effect of Fly Ash on Deformation of Roller- Compacted Concrete,” ACI Materials Journal, Vol. 103, No. 5, 2006, pp. 336-339

[35] http://en.wikipedia.org/wiki/Three_Gorges_Dam 2011.

[36] P. W. Gao, X. L. Lu, H. Lin, X. Li and J. Hou, "Effects of Fly Ash on the Properties of Environmentally Friendly Dam Concrete,” Fuel, Vol. 86, No. 7-8, 2007, pp. 12081211. doi:10.1016/j.fuel.2006.09.032

[37] ACAA 2008 CCP Report, American Coal Ash Association. acaa-usa.org.

[38] S. Wang and L. Baxter "Comprehensive Study of Biomass Fly Ash in Concrete: Strength, Microscopy, Kinetics and Durability,” Fuel Processing Technology, Vol. 88, No. 11-12, 2007, pp. 1165-1170. doi:10.1016/j.fuproc.2007.06.016

[39] S. Wang, A. Miller, E. Llamazos, F. Fonseca and L Baxter, "Biomass Fly Ash in Concrete: Mixture Proportioning and Mechanical Properties," Fuel, Vol. 87, No. 3, 2008, pp. 365-371. doi:10.1016/j.fuel.2007.05.026

[40] S. Wang, E. Llamazos, L. Baxter and F. Fonseca, "Durability of Biomass Fly Ash Concrete: Freezing and Thawing and Rapid Chloride Permeability Tests," Fuel, Vol. 87, No. 3, 2008, pp. 359-364. doi:10.1016/j.fuel.2007.05.027

[41] S. Wang, L. Baxter and F. Fonseca, "Biomass Fly Ash in Concrete: SEM, EDX and ESEM Analysis,” Fuel, Vol. 87, No. 3, 2008, pp. 372-379. doi:10.1016/j.fuel.2007.05.024

[42] S. Wang and L. Baxter, "Biomass Ash in Concrete-Mitigation of Alkali Silica Reactions (ASRs) Expansions with Different Opal Percentages,” Key Engineering Materials, Vol. 400-402, 2009, pp. 131-136. doi:10.4028/www.scientific.net/KEM.400-402.131

[43] A. Johnson, J. J. Catalan and S. D. Kinrade, "Characterization and Evaluation of Fly-Ash from Co-Combustion of Lignite and Wood Pellets for Use as Cement Admixture," Fuel, Vol. 89, No. 10, 2010, pp. 3042-3050. doi:10.1016/j.fuel.2010.05.027 